\title{
INSTITUTIONAL RESEARCH AGENDA EXECUTION THROUGH UNDERGRADUATE THESIS OUTPUT
}

\author{
Edgar Allan Dela Cruz Mendoza. Far Eastern University \\ emendoza@feu.edu.ph
}

\begin{abstract}
As the universities in the Philippines aspires to be among the leading institutions within ASEAN together with other ASEAN universities, research initiatives have been one of the way for them to internationalize. Research agenda were created to align all the efforts of the higher education institution towards few, if not one, foci. This paper is a formative evaluation of the initial execution of a certain autonomous university in the country. Utilization of the research agenda as well as the research capability of the advisers is looked into in this paper.

The 10-fold agenda, sixty eight (68) theses and thirty (30) faculty members, twenty (20) of which are thesis advisers, are used as data for the document analysis. Slovin's formula is shown to set the minimum required number of data needed. The census of the population is gathered. Descriptive statistics, such as frequency and percentage, are employed since the research is qualitative in nature.

Among the 68 theses analyzed, 6 are classified as Type A, 18 are Type B, and the rest are Type C. Scoring is based on the panel or paper critique done at the end of the semester. The bias is reduced through a ranking of score, instead of using the weighted mean to eliminate sensitivity to extreme values.

In its entirety, this research is valuable to the institution as its results could be used to improve the current system of the institution and further strengthen its research culture. At the end of this paper, a model is proposed to aid the other institution in formulating its own research agenda through internal and external assessment - TriFocal Assessment for Research Agenda Creation (TARAC).
\end{abstract}

Keywords: research agenda, undergraduate thesis, thesis advising, TARAC, 10-fold agenda

\section{INTRODUCTION}

With K-12 and ASEAN Mutual Recognition Agreement bugging the educational system in the Philippines, different higher educational institutions (HEIs) have been improving different aspects of its operations to keep at par with international standards.

In the Philippines, only four universities have always reached the QS rating for top universities in Asia namely University of the Philippines (UP), Ateneo de Manila University (AdMU), De La Salle University (DLSU), and 
University of Sto. Tomas (UST) (Geronino, 2015). Within the Philippines, only AdMU, DLSU, and UST are granted five (5) years of autonomous status by the Commission on Higher Education (CHED), while only $5 \%$ of all HEIs are autonomous with three (3) years and (1) year autonomous status. UP, on the other hand is under the Office of the Philippine President and thus stands as an entity not within the umbrella of CHED.

The focus of this study is one of the autonomous universities in the country with three (3) year grant. The university envisions being one of the top five universities in the Philippines following the list of HEIs above by 2020 . This paper is limited with the research initiative of one institute of that specific university through thesis advising. The highlight of this study is the match and skills inventory of the adviser through its set 10-fold agenda.

Aligning to the priorities of National Higher Education Research Agenda (NHERA) (CHED, 2013) with that of the university through its University Research Center, its institute pursues to be the tourism and hospitality education's pioneer in revitalizing research-stalled initiatives. Through this philosophy, the Institute is geared towards focusing its research endeavor in the following 10-fold agenda:

Agendum 1 - Tourism and Hospitality Policy Orientation and Formulation. This aspect focuses on legislative agenda of the Tourism Initiatives of the Congress through the House of Representatives and Senate, Department of Tourism (DOT), Department of Trade and Industry (DTI), and other related government agencies that deal with the operations of tourism and hospitality sectors.

Agendum 2 - Tourism and Hospitality Innovation. Trends and updates in the tourism and hospitality sectors are quite fast approaching in terms of consumer preferences and desires. In this manner, the Institute will be prepared and be updated of these changes in order to align to the needs of the market today.

Agendum 3 - Use of ICT in Tourism and Hospitality. Information is very substantial in all aspects whether in business or any other educational field. This has to be coupled with the communication efforts on how the information will be received by the right people through the right channel. Technology comes in the picture in order to lessen the time requirement of every transaction.

Agendum 4 - Educational Services in Tourism and Hospitality Programs. The educational services of all the private and public HEIs should be considered as another focal point considering the demand of the world labor market. The training ground of all Filipino Tourism and Hospitality professionals are rooted from the educational services of the country.

Agendum 5 - Relationship, Participation, Linkages and Exchange Programs. The university is also anchored on establishing worthwhile partnership in local and international arena wherein aspects such as research, facilities, exposure, and, student and faculty exchange programs are to be undertaken.

Agendum 6 - Quality Assurance. It is the foremost goal of every establishment to give $100 \%$ quality assurance to their stakeholders. In this concept, researchers may focus on the supply chain management up to the delivery to the customers especially services.

Agendum 7 - Manpower, Competencies and Labor Challenges. ASEAN MRAs' are naturally a big leap for the tourism and hospitality industry as well as 
the upgrading on the acquired competencies of the labor force based on their trainings with different learning facilities like HEIs, TESDA, other private training providers and professional assessment centers. This area may be a good starting point on how the stakeholders affected by this phenomenon reacted and prepared.

Agendum 8 - Tourism and Hospitality Businesses and Investments. It will always be a very sound proposal if the focus on the research involves the business and investments initiatives happening in the country. It may also focus on emerging industries, matured ones and the entry-level companies that are playing currently and focusing on specific market areas.

Agendum 9 - Sustainability, Nature, and Environmental Concerns. Continuous progress, maintaining the system and practices, relevance of nature preservation, environmental impact and climate change are some of the research areas that will tremendously help the existence of our Mother Earth. This aspect may be a very common proposal but very important at the same time.

Agendum 10 - Tourism and Hospitality Internal Business Environment. The operational requirement of every business allows for the reformulation and reengineering of company objectives and strategies. Tourism establishments, hotels, restaurants and institutional educations are no exception in the research proposals to be worked upon.

Figure 1. Factors Affecting Undergraduate Thesis Output

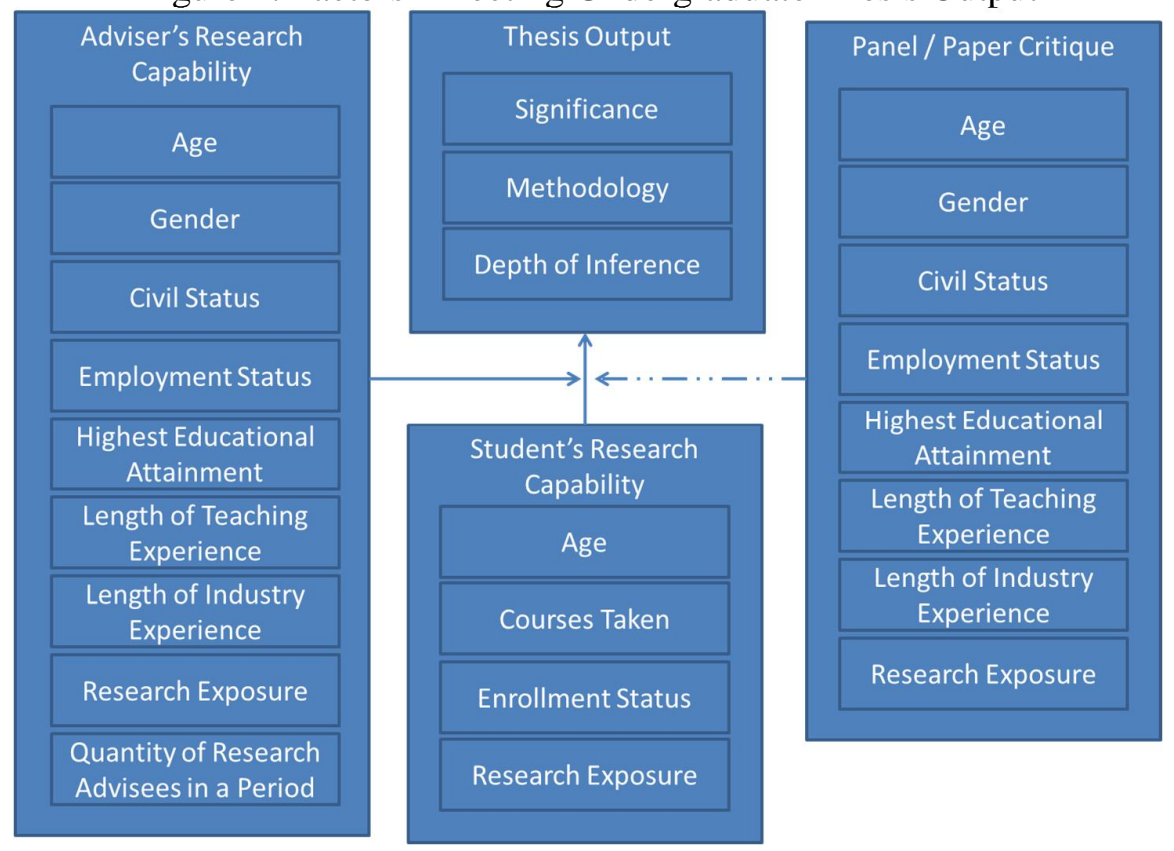

\section{OBJECTIVES}

As the university becomes a matured research institution, the institute contributes through fulfilling its 10 -fold agenda. This research addresses these objectives: to see the alignment of thesis output and expertise of the advisers with the 10-fold research agenda of the institute; to find the relation of demographic background of advisers to the thesis output; and, to generate recommendation as 
to how the institute could improve the research outputs of the students through the advisers.

Though this research follows the framework in Figure 1, this study did not include all factors that were not gathered such as advisers' research exposure, students' and panel members' demographics. Students' profile would be hard to analyze since their thesis is done in groups.

There is a dearth of literature on how research agendas have been developed (Bourke et al, 2015). This research is valuable to the institution as it evaluates the current advising policy and research agenda match. Results of this study could be used to improve the current system of the institution.

Another major contribution of this paper is its recommended framework in developing institutional agenda through the TARAC Model proposed in Figure 2. As compared to the study of Bourke et al, the context of this paper is within the tourism and hospitality industry. Nonetheless, the proposed TARAC Framework is applicable to other industries, as well.

\section{METHOD}

This research is descriptive in nature. Burns and Grove (2003) define descriptive research as a research designed to provide a picture of a situation as it naturally happens. Descriptive research may be used to justify current practice and make judgment, revalidate known theories, and also to develop new theories.

The data gathering done for this research is document analysis. Thesis outputs of the undergraduate tourism students last semester, Second Semester Academic Year 2015-2016 are collected and so with the profiles of all faculty members within the tourism department, those who acted as research advisers and those who did not.

The whole Census of the undergraduate thesis of the tourism majors and faculty member profiles were gathered and so sampling design and computation won't be presented. However, when Slovin's Formula is used:

where $\mathrm{n}=$ sample size

$$
n=\frac{N}{1+N e^{2}}
$$

$\mathrm{N}=$ total population of 30 faculty members

$\mathrm{e}=$ margin of error,

twenty eight (28) faculty members are needed to reach a $95 \%$ confidence level with $5 \%$ margin of error $(\alpha=0.05)$.

This research employs qualitative approach. Statistical analyses used are descriptive statistics only. Frequencies and percentages are utilized to describe the characteristics of the data gathered.

\section{RESULTS AND DISCUSSION}

At the end of the Second Semester of Academic Year 2015-2016, 68 undergraduate tourism theses were created by the institute's Bachelor of Science in Tourism Management students.

Thesis scores were generated from the panel defense set by the institute where all theses were presented in 9 different set of panel or paper critique, where each panel is composed of one chairman and 2 panel reactors.

Table 1. Classification of Thesis Output 


\begin{tabular}{|c|c|c|}
\hline Thesis & Frequency & Percentage \\
\hline Type A & 6 & $8.82 \%$ \\
\hline Type B & 18 & $26.47 \%$ \\
\hline Type C & 44 & $64.71 \%$ \\
\hline & 68 & $100.00 \%$ \\
\hline
\end{tabular}

Rank average is employed to determine the scores of each thesis to remove the bias of the panel members. With this process, the top-tier researches that reached the bracket score were classified Type A, the next bracket got 18 papers and were classified Type B, and the rest were classified as Type C.

This is the first year that the institute implemented its new 10-fold agenda as part of the university's way to reach its vision to be a top-tier university in the Philippines.

Table 2. Inclination the Thesis Output of the Student with the Research Agenda

\begin{tabular}{|c|c|c|c|}
\hline Agenda & Thesis & Percentage & Rank \\
\hline Agendum 1 & 24 & $35.29 \%$ & 2 \\
\hline Agendum 2 & 7 & $10.29 \%$ & 3 \\
\hline Agendum 3 & 2 & $2.94 \%$ & 6.5 \\
\hline Agendum 4 & 2 & $2.94 \%$ & 6.5 \\
\hline Agendum 5 & 4 & $5.88 \%$ & 4 \\
\hline Agendum 6 & 3 & $4.41 \%$ & 5 \\
\hline Agendum 7 & 0 & $0.00 \%$ & 9.5 \\
\hline Agendum 8 & 0 & $0.00 \%$ & 9.5 \\
\hline Agendum 9 & 25 & $36.76 \%$ & 1 \\
\hline Agendum 10 & 1 & $1.47 \%$ & 8 \\
\hline & 68 & $100.00 \%$ & \\
\hline
\end{tabular}

Among the ten agenda, Agenda 7 and 8 - Manpower, Competencies and Labor Challenges, and Tourism and Hospitality Businesses and Investments were the only ones not utilized by the students as they finish their capstone research for their degree.

Agendum 9 - Sustainability, Nature, and Environmental Concerns - is the most used followed by Agendum 1, Tourism and Hospitality Policy Orientation and Formulation. This is not unexpected since the students have already taken courses dealing with tourism impacts and sustainability, and tourism planning and development. Their course in ecotourism is taken together with their thesis that might have inspired them to work on such topics. 
Table 3. Demographics of the Faculty Members who are not Thesis Advisers

\begin{tabular}{|c|c|}
\hline \multicolumn{2}{|l|}{ Gender } \\
\hline Male & 4 \\
\hline Female & 6 \\
\hline \multicolumn{2}{|l|}{ Civil Status } \\
\hline Single & 5 \\
\hline Married & 5 \\
\hline \multicolumn{2}{|l|}{ Employment Status } \\
\hline Regular Full Time & 1 \\
\hline Lecturer Full Time & 5 \\
\hline Lecturer Part Time & 4 \\
\hline \multicolumn{2}{|c|}{ Highest Educational Attainment } \\
\hline Bachelor's Degree & 7 \\
\hline Professional Master's Degree & 3 \\
\hline Research Master's Degree & 0 \\
\hline Professional Doctorate & 0 \\
\hline Research Doctorate & 0 \\
\hline
\end{tabular}

Appendix A and B shows the demographic profiles of the faculty members of the tourism management department of the institute. Table 3 indicates the profile of the faculty who opted not to get thesis advisees. Most of these faculty members are currently in the process of finishing their graduate thesis and seasoned industry practitioner who cannot handle research load on top of their teaching loads.

Table 4 shows the demographic profile of the thesis advisers last term. Most of them are men, with $60 \%$, and the rest are women, with $40 \%$. As per their gender, $65 \%$ are single, and $35 \%$ of them are married. Sixty-five percent $(65 \%)$ works full time, while only $25 \%$ of the advisers are tenured. Three fourths or $75 \%$ has graduate degrees but only $10 \%$ has doctorate, and the remaining $25 \%$ are bachelor's degree holder who are exposed into research production

Table 4. Demographics of the Thesis Advisers

\begin{tabular}{|c|c|c|}
\hline Gender & Frequency & Percentage \\
\hline Male & 12 & $60.00 \%$ \\
\hline Female & 8 & $40.00 \%$ \\
\hline Total & 20 & $100.00 \%$ \\
\hline Civil Status & Frequency & Percentage \\
\hline Single & 13 & $65.00 \%$ \\
\hline Married & 7 & $35.00 \%$ \\
\hline Total & 20 & $100.00 \%$ \\
\hline Employment Status & Frequency & Percentage \\
\hline Regular Full Time & 5 & $25.00 \%$ \\
\hline Lecturer Full Time & 8 & $40.00 \%$ \\
\hline
\end{tabular}




\begin{tabular}{|c|c|c|}
\hline Lecturer Part Time & 7 & $35.00 \%$ \\
\hline Total & 20 & $100.00 \%$ \\
\hline Highest Educational Attainment & Frequency & Percentage \\
\hline Bachelor's Degree & 5 & $25.00 \%$ \\
\hline Professional Master's Degree & 9 & $45.00 \%$ \\
\hline Research Master's Degree & 4 & $20.00 \%$ \\
\hline Professional Doctorate & 1 & $5.00 \%$ \\
\hline Research Doctorate & 1 & $5.00 \%$ \\
\hline Total & 20 & $100.00 \%$ \\
\hline
\end{tabular}

The above table shows the complete roster of the faculty advisers. The next tables would indicate only the list of those that have produced thesis output that are classified Type A and B.

Table 5. Degree Attained by Adviser

\begin{tabular}{|c|c|c|}
\hline Highest Educational Attainment & Type A & Type B \\
\hline Bachelor's Degree & 1 & 2 \\
\hline Professional Master's Degree & 3 & 6 \\
\hline Research Master's Degree & 0 & 2 \\
\hline Professional Doctorate & 1 & 1 \\
\hline Research Doctorate & 1 & 1 \\
\hline
\end{tabular}

Most of the Type A and Type B thesis were advised by professional master's degree holder advisers. This result is not unexpected since most of the advisers fall under this highest educational attainment.

It's interesting to note that: 1) a bachelor's degree holder could produce a Type A and B thesis through its advisee; 2) though a research master's degree is trained the faculty in research, this doesn't equate to being a trained research adviser; and 3) a doctorate degree, be it professional or research, equipped the faculty to produce both Type A and Type B papers, though not all of their advisees fall on those category.

Table 6. Gender of Adviser

\begin{tabular}{|c|c|c|}
\hline Gender & Type A & Type B \\
\hline Male & 2 & 6 \\
\hline Female & 3 & 6 \\
\hline
\end{tabular}

Table 6 shows the gender of the advisers that produced Type A and B thesis. The numbers are almost, if not, the same. Gender, in this case, doesn't affect the advising process.

Table 7. Civil Status of Adviser

\begin{tabular}{|c|c|c|}
\hline Civil Status & Type A & Type B \\
\hline Single & 3 & 8 \\
\hline Married & 2 & 4 \\
\hline
\end{tabular}


Most of the advisers for both Type A and Type B thesis are single. This is expected since most of the advisers are single. In essence, civil status doesn't affect the advising, as well.

Table 8. Employment Status of Adviser

\begin{tabular}{|c|c|c|}
\hline Employment Status & Type A & Type B \\
\hline Regular Full Time & 2 & 4 \\
\hline Lecturer Full Time & 4 & 6 \\
\hline Lecturer Part Time & 0 & 2 \\
\hline
\end{tabular}

Employment status, as shown in table 8, affects the advising process. Most of those that have produced Type A and B papers are full time faculty employees. This gives them more time in the university to advise and do research, if they may. Tenure, though, doesn't affect advising. Being tenured doesn't mean one would be a better adviser.

As the university becomes a matured research institution, tenured faculty members are expected to be more matured when it comes to research as compared to the non-tenured ones as this promotes research productivity of the institution. A note should be taken, as well, that some non-tenured and new faculty members might have come from a more matured research institution.

Table 9. Inventory of Adviser Inclination with the Research Agenda

\begin{tabular}{|c|c|c|c|}
\hline Agenda & $\begin{array}{c}\text { Advisers' } \\
\text { Inclination }\end{array}$ & Percentage & Rank \\
\hline Agendum 1 & 16 & $21.62 \%$ & 2 \\
\hline Agendum 2 & 9 & $12.16 \%$ & 3 \\
\hline Agendum 3 & 2 & $2.70 \%$ & 8 \\
\hline Agendum 4 & 6 & $8.11 \%$ & 5 \\
\hline Agendum 5 & 2 & $2.70 \%$ & 8 \\
\hline Agendum 6 & 6 & $8.11 \%$ & 5 \\
\hline Agendum 7 & 1 & $1.35 \%$ & 10 \\
\hline Agendum 8 & 24 & $32.43 \%$ & 1 \\
\hline Agendum 9 & 2 & $2.70 \%$ & 8 \\
\hline Agendum 10 & 6 & $8.11 \%$ & 5 \\
\hline & 74 & $100.00 \%$ & \\
\hline
\end{tabular}

Most faculty members have expertise in Agenda 8 and 1 - Tourism and Hospitality Businesses and Investments, and Tourism and Hospitality Policy Orientation and Formulation. This result is found to be expected since most of the advisers have a professional master's degree in business and have worked as managers in the tourism and hospitality industry.

With the case of Agendum 7 - Manpower, Competencies and Labor Challenges - only one faculty member, yet, has focused in human resource and labor issues. 
Of all the 68 theses, only 18 or $26 \%$ are matched with the advisers' academic background. Intervention has to be done to increase the percentage. Since the students are into Agendum 9, seminars regarding environmental science, management, planning, and tourism could be put to place to equip the advisers to handle research on this agenda. Ideally, advisers could only take advisees studying within their research capability and interest but since there's a lack in some research expertise they are allowed to accept research that they think they could help with without compromising the quality of the paper and the research process learned by the student.

Since only descriptive statistics are used in this study, further inference and generalization could not be created. It is recommended though to: 1) include the research design and the approach in analyzing the adviser-advisee match;2) include the adviser demographic profiles in further study to see if the other factors affect the thesis output of the advisees; and 3) to use inferential statistics to determine correlation of the output using the advisers' demographic profile and students' research outputs.

Some knowledge created through research are industry exclusive, examples in the services industry are Parasuraman, Zeithaml, and Berry (1985), Rust and Chung (2006), Vargo and Lusch (2004); in the tourism industry are Irritation Index or Irridex (Doxey, 1975), Tourist Area Life Cycle (Butler, 1980), Social Representations Theory (Moscovici, 1981, 1983, 1988; Pearce et aI., 1996), Stakeholder Theory (Freeman, 1984), Growth Machine Theory (Canan and Hennessy, 1989; Molotch, 1976; Molotch and Logan, 1984), Play and Compensation Theory (Bystrzanowski, 1989), Attribution Theory (Pearce, 1989), Equity Theory (Pearce et aI., 1991), Social Exchange Theory (Ap, 1992; Blau, 1964; Homans, 1961; Perdue et aI., 1987), and Power Theory (Kayat, 2002). Universities, then, need to focus their research initiatives towards certain research agenda.

Since this research focuses on the analysis of the institute's 10-fold research agenda, a recommendation as to how an institution could create the same are indicated below. The researcher recommends the use of internally and externally analysis in determining the institutions' research agenda.

Internal assessment is done through finding the link between the capability of the faculty and students and the research inclination of the institution itself. University agendas, for example, may emerge from specific teams or leading researchers who have identified more nuanced research approaches for a particular field (Becker et al., 2013; Gedajlovic, Honig, Moore, Payne, \& Wright, 2013). Assessment through the faculty and researcher is one part.

External assessment is empowered by the outside forces that shape the research focus of the institution through its local community, initiatives of the national government, and the international trends for research. 


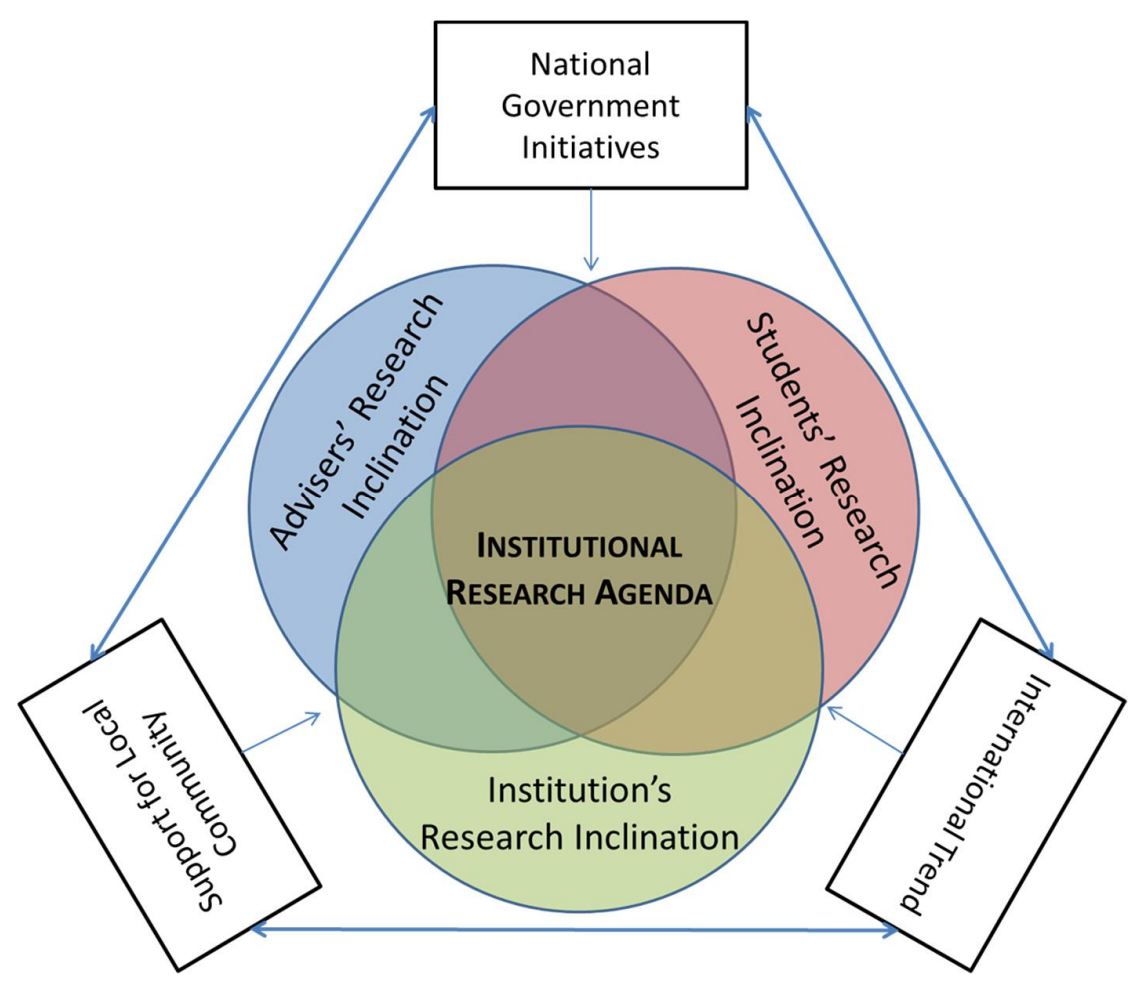

Figure 2. Tri-focal Assessment for Research Agenda Creation (TARAC)

\section{NoTES}

1. This study did not use inferential statistics and thus generalization is not appropriate.

2. Only a test case is used in this study, a more conclusive data should be gathered from a higher number of higher education institutions is needed to produce a generalization.

3. Inclinations of students, panel/paper critique, and faculty-in-charge for thesis are not included. 


\section{REFERENCES}

Ap, J. (1992). Residents' Perceptions on Tourism Impacts, Annals of Tourism Research. 19(4),665-690

Becker, W. C., Fraenkel, L., Kerns, R. D., \& Fiellin, D. A. (2013). A research agenda for enhancing appropriate opioid prescribing in primary care. Journal of General Internal Medicine, 28(10), 1364-1367.

Blau, P.M. (1964). Exchange and Power in Social Life. New York: Wiley Homans, C.G, 1961, Social Behaviour: Its Elementary Forms. New York: Harcourt Brace

Bourke, L., Best, J. D., Wakerman, J., Humphreys, J. S., \& Wright, J. R. (2015). Reflection on the development of a research agenda in rural health. Journal of Research Practice, 11(1), Article M1. Retrieved from http://jrp.icaap.org/index.php/jrp/article/view/470/415

Butler, R.W. (1980). The Concept of Tourism Area Cycle of Evolution: Implications for Management of Resources, Canadian Geographer. 24(1), 512

Burns, S.N., and Grove, S.K. (2003). Understanding nursing research. 3rd edition. Philadelphia: Saunders.

Bystrzanowski, J. (1989). Tourism as a Factor of Change: A Socio-cultural Study. Vienna: Centre for Research and Documentation in Social Sciences

Canan, P., and Hennessy, M. (1989). The Growth Machine, Tourism, and the Selling of Culture, Sociological Perspectives. 32(2), 227-243

Commission on Higher Education (CHED), (2013). National Higher Education Research Agenda 2 2009-2018.

Doxey, G. (1975). A Causation Theory of Visitor-Residents Irritants: Methodology and Research Inferences. In: Travel and Tourism Research Associations Sixth Annual Conference Proceedings, pp. 195-198. San Diego, CA: ITRA

Freeman, R. (1984). Strategic management: A stakeholder approach. Boston: Pitman

Gedajlovic, E., Honig, B., Moore, C. B., Payne, G. T., \& Wright, M. (2013). Social capital and entrepreneurship: A schema and research agenda. Entrepreneurship Theory and Practice, 37(5), 455-78. 
Geronimo, J.Y. (2015). 4 PH schools make it to Asian university rankings again. Rapler: Manila. Retrieved from http://www.rappler.com/nation/95860philippines-universities-2015-qs-university-rankings-asia

Kayat, K., (2002). Power, social exchanges and tourism in Langkawi: Rethinking resident perceptions, International Journal of Tourism Research. 4(3), 171191

Molotch, H., (1976). The city as a growth machine: Toward a political economy of place. The American Journal of Sociology, 82(2).309-332

Molotch, H., and Logan, J. (1984). Tension in the Growth Machine: Overcoming Resistance to Value-Free Development, Social Problems. 31 (5),483-499

Moscovici, S. (1981). On Social Representations. In J.P. Forgas. Soeia. Cognition: Perspectives on Everyday Understanding, pp. 181-209. London: Academic Press

Moscovici, S. (1983). The Coming Era of Social Representations. In J.P. Codol and J.P. Leyens (Eds), Cognitive Approaches to Social Behaviour. The Hague: Nijholl'

Moscovici, S. (1988). Notes toward a description of social representations. European Journal of Social Psychology. 18, 211-250

Parasuraman, A., Zeithaml V.A., and Berry, L.L. (1985), "A Conceptual Model of Service Quality and Its Implications for Future Research," Journal of Marketing, 49 (Fall), 41-50.

Pearce, D.G. (1989), Tourist Development. New York: Longman

Pearce, P.L., Moscardo, G., and Ross, O.F. (1991). Tourism impact and community perception: An equity-social representational perspective, Australian Psychologist. 26(3). 147-152

Pearce, P.L., Moscardo, G., and Ross, O.F. (1996). Tourism Community Relationships. Oxford: Pergamon

Perdue, R.R., Long, P.T., and Allen, L. (1987). Rural Resident Tourism Perceptions and Attitudes, Annals of Tourism Research. 14(3).420-429

Rust, Roland T. and Tuck Siong Chung (2006), "Marketing Models of Service and Relationships," Marketing Science, 25 (6), 560-80.

Vargo, Stephen L. and Robert F. Lusch (2004), "Evolving to a New Dominant Logic for Marketing," Journal of Marketing, 68 (January), 1-17. 
Appendix A. Demographics of Thesis Advisers

\begin{tabular}{|c|c|c|c|c|c|}
\hline Adviser & $\begin{array}{c}\text { Highest } \\
\text { Educational } \\
\text { Attainment }\end{array}$ & Gender & $\begin{array}{c}\text { Civil } \\
\text { Status }\end{array}$ & $\begin{array}{c}\text { Employment } \\
\text { Status }\end{array}$ & $\begin{array}{c}\text { Length of } \\
\text { Teaching } \\
\text { Experience }\end{array}$ \\
\hline 1 & MBA & Female & Single & LFT & 27 \\
\hline 2 & BS & Female & Single & LFT & 2 \\
\hline 3 & MBA & Male & Single & RFT & 4 \\
\hline 4 & DBA & Male & Single & RFT & 10 \\
\hline 5 & MS & Female & Married & LPT & 9 \\
\hline 6 & MBA & Female & Married & RFT & 6 \\
\hline 7 & PHD & Female & Married & RFT & 14 \\
\hline 8 & BS & Female & Single & LFT & 12 \\
\hline 9 & MS & Male & Single & LPT & 6 \\
\hline 10 & MBA & Male & Married & LPT & 6 \\
\hline 11 & MS & Male & Single & LPT & 5 \\
\hline 12 & BS & Male & Married & LPT & 10 \\
\hline 13 & BS & Male & Single & LFT & 3 \\
\hline 14 & MBA & Female & Married & LFT & 19 \\
\hline 15 & MS & Female & Married & RFT & 4 \\
\hline 16 & MBA & Male & Single & LFT & 4 \\
\hline 17 & MBA & Male & Single & LFT & 0 \\
\hline 18 & BS & Male & Single & LPT & 2 \\
\hline 19 & MBA & Male & Single & LFT & 9 \\
\hline 20 & MBA & Male & Single & LPT & 16 \\
\hline
\end{tabular}

Appendix B. Thesis Turnout of the Advisers

\begin{tabular}{|c|c|c|c|c|c|c|}
\hline Adviser & Type A & Type B & Type C & & Average & Rank \\
\hline 1 & $1(16.67 \%)$ & $2(33.33 \%)$ & $3(50 \%)$ & $6(100 \%)$ & 1.67 & 4.5 \\
\hline 2 & $0(0 \%)$ & $0(0 \%)$ & $5(100 \%)$ & $5(100 \%)$ & 1.00 & 14 \\
\hline 3 & $0(0 \%)$ & $1(100 \%)$ & $0(0 \%)$ & $1(100 \%)$ & 2.00 & 2.5 \\
\hline 4 & $1(14.29 \%)$ & $2(28.57 \%)$ & $4(57.14 \%)$ & $7(100 \%)$ & 1.57 & 7 \\
\hline 5 & $0(0 \%)$ & $1(33.33 \%)$ & $2(66.67 \%)$ & $3(100 \%)$ & 1.33 & 17 \\
\hline 6 & $0(0 \%)$ & $0(0 \%)$ & $4(100 \%)$ & $4(100 \%)$ & 1.00 & 17 \\
\hline 7 & $1(20 \%)$ & $1(20 \%)$ & $3(60 \%)$ & $5(100 \%)$ & 1.60 & 6 \\
\hline 8 & $0(0 \%)$ & $2(50 \%)$ & $2(50 \%)$ & $4(100 \%)$ & 1.50 & 9 \\
\hline 9 & $0(0 \%)$ & $0(0 \%)$ & $1(100 \%)$ & $1(100 \%)$ & 1.00 & 17 \\
\hline 10 & $0(0 \%)$ & $0(0 \%)$ & $5(100 \%)$ & $5(100 \%)$ & 1.00 & 17 \\
\hline 11 & $0(0 \%)$ & $0(0 \%)$ & $1(100 \%)$ & $1(100 \%)$ & 1.00 & 17 \\
\hline 12 & $0(0 \%)$ & $0(0 \%)$ & $1(100 \%)$ & $1(100 \%)$ & 1.00 & 17 \\
\hline 13 & $1(33.33 \%)$ & $0(0 \%)$ & $2(66.67 \%)$ & $3(100 \%)$ & 1.67 & 4.5 \\
\hline 14 & $2(50 \%)$ & $1(25 \%)$ & $1(25 \%)$ & $4(100 \%)$ & 2.25 & 1 \\
\hline 15 & $0(0 \%)$ & $1(25 \%)$ & $3(75 \%)$ & $4(100 \%)$ & 1.25 & 12 \\
\hline 16 & $0(0 \%)$ & $1(20 \%)$ & $4(80 \%)$ & $5(100 \%)$ & 1.20 & 13 \\
\hline
\end{tabular}




\begin{tabular}{|c|c|c|c|c|c|c|}
\hline 17 & $0(0 \%)$ & $1(100 \%)$ & $0(0 \%)$ & $1(100 \%)$ & 2.00 & 2.5 \\
\hline 18 & $0(0 \%)$ & $1(50 \%)$ & $1(50 \%)$ & $2(100 \%)$ & 1.50 & 9 \\
\hline 19 & $0(0 \%)$ & $2(50 \%)$ & $2(50 \%)$ & $4(100 \%)$ & 1.50 & 9 \\
\hline 20 & $0(0 \%)$ & $0(0 \%)$ & $2(100 \%)$ & $2(100 \%)$ & 1.00 & 17 \\
\hline
\end{tabular}

